\section{Digital curation}

The Northeast Document Conservation Center (NEDCC) is presenting a two-day conference, "The Techtonics of Digital Curation: a Symposium on the Shifting Preservation and Access Landscape," May 25-26, 2010, at the Massachusetts Institute of Technology (MIT) in Cambridge.

The symposium will examine our increasingly networked environment, and cover divergence and complexity in information networking, open access to scholarly communication, electronic copyright and intellectual property, collaborative and commercial preservation models, digital preservation repositories, digital archiving strategies, the networked self, and preservation of community-built digital creations.

The faculty includes Julie Cohen of Georgetown University, Paul Conway of the University of Michigan, Martin Halbert of the University of North Texas, Peter Hirtle of Cornell University, Gregory Jackson of EDUCAUSE, Brewster Kahle of the Internet Archive, Heather Piwowar of the University of Pittsburgh, MacKenzie Smith of MIT, Megan Winget of the University of Texas-Austin, and Ann Wolpert of MIT.

The symposium costs $\$ 325$ (\$275 for students), and the registration deadline is May 14, 2010. For more information, go to www.nedcc.org.

\section{Booklet about damaged books}

The Preservation Advisory Centre of the British Library (BL) has published Damaged Books, a basic introduction to the causes of and remedies for damage to bound volumes.

The 16-page booklet describes in general terms the parts of a book, inherent causes of deterioration, external causes of damage (en-

Jane Hedberg is senior preservation program officer at Harvard University Library, e-mail: jane_hedberg@ harvard.edu; fax: (617) 496-8344 vironment, handling, and storage), selection of volumes for remedial action, identification of types of damage, appropriate conservation treatments, and measures that can be taken to protect volumes before damage occurs. It could be useful for explaining to a lay audience how libraries conduct preservation activities and how to properly care for a personal library.

The booklet is available as a free PDF (340KB) at www.bl.uk/npo/pdf/damaged. pdf.

\section{Preservation challenges}

The Preservation Advisory Centre of the BL held a conference, "Doing more with less?' Forum on Skill Development," November 30, 2009.

Helen Shenton delivered the keynote presentation "Strategic Challenges for Preservation in Libraries and Archives." Shenton was head of collection care at BL and is now deputy director of the Harvard University Library.

Other presentations included "Preservation Training Needs in Research Libraries UK and Higher Education Libraries" by Jane Arthur of BL, "The Benefits of Partnerships in Preservation Projects" by Sheila Hingley of Durham University Library, "Action Conservation: Engaging Volunteers Hands-On" by Vicki Marsland of the National Trust, "Digital Preservation-What Do I Need to Know?" by William Kilbride of the Digital Preservation Coalition, "Modern Materials: New Problems, New Skills?" by Cordelia Rogerson of BL, and "Preservation Advisory Centre's Skills Development Programme” by Caroline Peach of BL.

The keynote is available as an audio file (in two parts, each runs just under 15 minutes), and the other presentations are available as slides with text and images free-of-charge at www.bl.uk/npo/forum. html\#present. n 